\title{
Past, present, and future geographic range of an oro-Mediterranean Tertiary relict: The juniperus drupacea case study
}

\author{
Łukasz Walas $^{1} \cdot$ Karolina Sobierajska $^{1} \cdot$ Tolga Ok $^{2} \cdot$ Ali A. Dönmez $^{3}$. Salih S. Kanoğlu ${ }^{4} \cdot$ Magda Bou Dagher-Kharrat $^{5}$. \\ Bouchra Douaihy ${ }^{6} \cdot$ Angel Romo $^{7}$ • Jean Stephan ${ }^{8} \cdot$ Anna K. Jasińska $^{1} \cdot$ Adam Boratyński $^{1}$ (D)
}

Received: 9 August 2018 / Accepted: 15 March 2019 / Published online: 24 April 2019

(C) The Author(s) 2019

\begin{abstract}
Juniperus drupacea is a unique relict species found in the mountains of southern Greece, southern Turkey, and western Syria and Lebanon. The aim of this study was to describe the natural range of this juniper by determining the current locations of its populations and to predict a theoretical range for the species based on current, past, and future climatic conditions. We used data from the literature, herbarium materials, and our unpublished field notes (about 500 georeferenced points in total) to determine the current natural distribution of $J$. drupacea (realized niche). To predict suitable conditions with the program MaxEnt, we used data from the WordClim database, which allowed estimation of the potential niche. The potential niche of J. drupacea was much wider during the Last Glacial Maximum (LGM) and was severely restricted during the Eemian interglacial period. Depending on the climate scenario, this species could become endangered in the future due to climate changes. Considering the relatively restricted geographic range of $J$. drupacea and the decreasing numbers of localities where it is found, conservation strategies should be adopted to allow for preservation of its genetic and morphological diversity.
\end{abstract}

Keywords Biodiversity $\cdot$ Climate change $\cdot$ Niche modeling $\cdot$ Relict tree

Editor: Wolfgang Cramer.

Electronic supplementary material The online version of this article (https://doi.org/10.1007/s10113-019-01489-5) contains supplementary material, which is available to authorized users.

Anna K. Jasińska

ak.jasinska@zapasowe.com.pl

Adam Boratyński

borata@man.poznan.pl

Łukasz Walas

lukaswalas@wp.pl

Karolina Sobierajska

karsob@man.poznan.pl

Tolga Ok

tolgaok@ksu.edu.tr

Ali A. Dönmez

donmez@hacettepe.edu.tr

Salih S. Kanoğlu

salih@ngbb.org.tr

Magda Bou Dagher-Kharrat

boudagher@ fs.usj.edu.lb

Bouchra Douaihy

bouchradouaihy@gmail.com
Angel Romo

angel.romo@gmail.com

Jean Stephan

dr.jeanstephan@gmail.com; jean.stephan@ul.edu.lb

1 Institute of Dendrology, Polish Academy of Sciences, Parkowa 5, 62-035 Kórnik, Poland

2 Department of Forest Botany, Faculty of Forestry, Sütçü İmam University, Kahramanmaraş, Turkey

3 Department of Biology, Faculty of Science, Hacettepe University, Ankara, Turkey

4 Nezahat Gökyiğit Botanik Garden, Istanbul, Turkey

5 Laboratoire 'Caractérisation Génomique des Plantes', Faculté des Sciences, Université Saint-Joseph, Beirut, Lebanon

6 Department of Earth and Life Sciences, Faculty of Sciences III, Lebanese University, Tripoli, Lebanon

7 Botanical Institute of Spanish Research Council, Barcelona, Spain

8 Department of Life and Earth Sciences, Faculty of Sciences 2, Lebanese University, Fanar, Lebanon 


\section{Introduction}

The Syrian juniper (Juniperus drupacea Labill.) is a Tertiary relict (Palamarev 1989) that currently occurs in a restricted area (Browicz 1982). This exceptional tree is the only representative of the section Caryocedrus Endl. of the genus Juniperus L. (Adams 2014) and is conspicuous with extremely large seed cones and connected seeds that form a drupe-like structure (Eliçin 1977; Boratyński and Browicz 1982; Maerki and Frankis 2015). This feature was the motivation for placing J. drupacea in its own genus Arceuthos Antoine \& Kotschy; however, this is now generally treated as a synonym of Juniperus L. (Coode and Cullen 1965; Gaussen 1968; Christensen 1997; Farjon 2005; Adams 2014).

Juniperus drupacea is a tree that generally grows to a height of about $15-20 \mathrm{~m}$ with a stem reaching $60-80-\mathrm{cm}$ diameter (Yaltırk 1993; Christensen 1997), though one individual was measured at $40 \mathrm{~m}$ in height (Karaca 1994). The current geographical range of $J$. drupacea covers the southern Peloponnese in Europe (Boratyński and Browicz 1982; Tan et al. 1999; Maerki and Frankis 2015), southern Turkey, western Syria, Lebanon, and the northernmost region of Israel in Asia (Mouterde 1966; Browicz 1982; Yaltırk 1993; Talhouk et al. 2001). The species is a component of Abies cephalonica Loudon forests in the mountains of Peloponnese in Europe and Abies cilicica (Antoine \& Kotschy) Carrière, Pinus nigra Arnold, and Cedrus libani A. Rich. forests in the mountains of Asia. In the supra-Mediterranean layer of Lebanon, it is found with Quercus coccifera L., Q. infectoria Oliv., and Q. cerris L. (Abi-Saleh et al. 1996). In addition, it forms woodlands with other juniper species in areas previously occupied by forests or on abandoned fields (Zohary 1973; Browicz 1982; Mayer and Aksoy 1986). The occurrence of $J$. drupacea in the Asiatic part of its geographic range is discontinuous, with most localities found in areas recognized as refugia of Tertiary floras, including Central and East Taurus, Amanos, and the Lebanon mountains (Médail and Diadema 2009, p. 1336). This pattern of distribution underlines the relict's tertiary origin. The ancestor of $J$. drupacea probably diverged between the Eocene and Oligocene epochs (Mao et al. 2010). During the late Tertiary and early Quaternary, it was probably a component of the Tethyan and, subsequently, the Mediterranean sclerophyll flora (Palamarev 1989; Kvaček 2002; Palamarev et al. 2005); however, its palaeo-remnants are very scarce (Stockey et al. 2005). It was affected by relatively high temperatures and water deficits during the Messinian salt crisis, and afterward, during the Pliocene and Pleistocene, exposed to climate cooling and oscillations in temperature, which finally reduced its geographic range to the current area.

As a component of oro-Mediterranean communities, $J$. drupacea is a light-demanding tree and only young seedlings survive in shade. The species is moderately thermophilic
(Zohary 1973; Yaltırık 1993), but less drought-tolerant than other junipers (Douaihy et al. 2017). These properties allowed J. drupacea to survive the Pleistocene climate oscillations in mountainous regions where it migrated to lower elevations during the cold glacial stages and to higher elevations during the warm interglacial periods, as did many other tree species (Hewitt 2004; Eastwood 2004; Thompson 2005). Its numbers most likely decreased during more humid periods due to competition with more moisture-demanding trees, but might have increased during drier periods, as described for other juniper species (Carrión et al. 2001; Carrión 2002; Hajar et al. 2008; Orland et al. 2012). It is also possible that reduction of fir and cedar forests by humans, together with other human activities during recent millennia, allowed for the extension of juniper woodlands with $J$. drupacea (Talhouk et al. 2001; Fady et al. 2008; Douaihy et al. 2011, 2012, 2013; Awad et al. 2014).

Recently, the geographic pattern of genetic and morphological structures of $J$. drupacea has been surveyed (Sobierajska et al. 2016), with identification of six groups of populations which differed genetically: two European, three Turkish, and one Lebanese. This could imply the possible origin from another region and/or long-lasting spatial isolation, together with different reaction of populations from these parts of the species geographic range to the environmental conditions. The differences between European, Turkish, and Lebanese $J$. drupacea were also detected in their essential oil compositions (Adams et al. 2017).

According to the International Union for Conservation of Nature (IUCN), J. drupacea is a species of "least concern," with a stable population trends at the global scale (Gardner 2013); however, the European (Gardner 2017) and Lebanese populations (Bou Dagher, personal communication) are considered threatened. Studies of $J$. drupacea distribution on the Peloponnese indicate that their conservation status was vulnerable due to very slow regeneration (Maerki, personal communication).

In Lebanon, cutting of $J$. drupacea is forbidden by law. In that country, it is present in cedar biosphere reserves at Jabal Moussa and Shouf, as well as in other areas under protection. The main current threat in Lebanon is an outbreak of the dwarf mistletoe Arceuthobium oxycedri (DC.) Bieb. (Douaihy et al. 2017; Gardner 2013). In addition, the difficulty in germinating $J$. drupacea seed means that it is not a component of forest restoration activities in Lebanon.

The maintenance of $J$. drupacea in Turkey is also under forest legislation, which includes juniper species as protected elements of the forest. It is also conserved in 11 national parks established in the Mediterranean area of Turkey and therefore, there is no distinct threat in the Turkish territory. The use of the fleshy cones by local human populations for the production of pekmez does not threaten the species (Kani Işık, Tolga Ok, and Ali Dönmez personal communication). 
Ongoing climate warming and aridization will influence the geographic range of organisms (Case and Lawler 2017; Tang et al. 2017). The influence of the climate warming on woody, long-lived species in the Mediterranean region was demonstrated for Laurus nobilis L. (Rodríguez-Sanchéz and Arroyo 2008) and Cedrus atlantica (Endl.) Manetti ex Carrière (Cheddadi et al. 2009). Similar studies were conducted with Juniperus excelsa M. Bieb. in the central part of Turkey (Özkan et al. 2015), Q. coccifera L. in the Levantine countries (Al-Qaddi et al. 2017), and Taxus baccata L. in Morocco (Romo et al. 2017). A potential impact of climate changes beginning in the Pliocene through modern times up to the end of the twenty-first century within the entire area of distribution was verified only for laurel and cedar. Impacts on Laurus nobilis were possible due to the relatively high number of subfossil remnants available and the large amount of accessible data on current localities. The subfossil data for Cedrus atlantica, although restricted, documented the species distribution in the mountains of north-western Africa and allowed for the approximation of palaeo-climate data and delineation of the species geographic range. Together with the climatic factors determining its current distribution, the region with favorable climate conditions for $C$. atlantica into the future was determined.

The subfossil data for junipers are very scarce due to their evolutionary origin and occurrence in arid regions, which reduces the probability of remnant conservation (e.g., Willis and McElwain 2002; Kvaček 2002; Palamarev et al. 2005; Stockey et al. 2005; Velitzelos et al. 2014). Additionally, pollen grains of juniper species are indistinguishable (e.g., Eastwood 2004; Tzedakis 2004). Thus, any retrospective evaluation and prediction of $J$. drupacea's geographic range can only be based on its current distribution. Therefore, identification of J. drupacea occurrence is essential for monitoring demographic processes connected with climate change and for determining conservation needs. We aimed to (1) present the current distribution of J. drupacea and (2) define the bioclimatic parameters that determine its current localities. With this information, we (3) defined the geographic range of the species in the past and (4) predicted the potential impact of global climate change on its geographic range in the future. Taking into account the genetic and morphological differences between European (PEL), Turkish (AN), and Lebanese (LEB) populations of the species (Sobierajska et al. 2016; Adams et al. 2017), we intend also to verify its adaptation to local climate and reaction to climate changes.

\section{Materials and methods}

Data on the distribution of $J$. drupacea were extracted from the literature and the labels of herbarium materials. The most important collections are preserved in the herbaria of the British
Museum (BM), the Botanical Garden of Edinburgh (E), Kew Gardens (K), the Istanbul Universities (ISTE and ISTO), the Universities of Ankara (ANK, HUB, and HUEF), the Naturhistorisches Museum Wien (W), the University of Patras (UPA), the Goulandris Natural History Museum (ATH), and the Institute of Dendrology Kórniks (KOR). Additionally, many field notes were made during the authors' expeditions, starting in the 1970s. When absent in the original documentation, the geographic coordinates (latitude, longitude, and altitude) were retrieved from Google Earth for every locality. Vague descriptions of locality, mostly historical in nature, which did not specify such information, were excluded from the analyses. We gathered more than 900 sets of location data, the great majority of them replicated in different herbaria and literature. From this data, we selected information for about 500 localities with sufficiently detailed geographic coordinates and altitudes (Supplementary Material, Table S1).

Bioclimatic variables were downloaded from the WorldClim database (Hijmans et al. 2005). We analyzed 19 variables (see Table 1) and altitude influences to determine the realized, retrospective, and predicted niches of $J$. drupacea; however, data concerning temperature and precipitation with altitude were generally recognized as the most important (Bradie and Leung 2017). Additionally, Emberger's pluviometric quotient $(Q)$ (Emberger 1955) was calculated using the Environmental Rasters for Ecological Modeling (Envirem) R package (Title and Bemmels 2018) according to the formula:

$$
Q=\frac{2000 P}{(M+m+546.4) \times(M-m)}
$$

where $P$ is the mean annual precipitation, $M$ is the mean maximum temperature of the warmest month, and $m$ is the mean minimum temperature of the coldest month.

Data from CAPE Last Interglacial Project (Otto-Bliesner et al. 2006) were used for the interglacial period (about $125 \mathrm{ka}$ BP). For the Last Glacial Maximum (LGM, about $22 \mathrm{ka} \mathrm{BP}$ ) and mid-Holocene (about $6 \mathrm{ka} \mathrm{BP}$ ), data from Community Climate System Model (CCSM, Gent et al. 2010) were used. Data for past climate were downscaled and calibrated (bias corrected) using WorldClim 1.4 as the baseline "current" climate. The current and interglacial periods had 30-s (about $900 \mathrm{~m}$ at the equator) resolution, while the LGM, Holocene optimum, and future prevision used a 2.5$\min$ (about $4.5 \mathrm{~km}$ at the equator) resolution. Two scenarios of future climate were selected as follows: RCP2.6 and RCP8.5 (Collins et al. 2013). The first scenario provided an increase of radiative forcing by $2.6 \mathrm{~W} \mathrm{~m}^{-2}$ before the year 2100 and an increase of average temperature by $1{ }^{\circ} \mathrm{C}$ before the year 2065 , while RCP8.5 provided an increase of radiative forcing by 8 . $5 \mathrm{~W} \mathrm{~m}^{-2}$ before the year 2100 and an increase of average temperature by $2{ }^{\circ} \mathrm{C}$ before the year 2065 . 
Prediction of range was performed using the MaxEnt 3.3.3k software (Phillips et al. 2006). It used data related to sites of species localities. To estimate the probability of occurrence of a species outside the known area of distribution and to evaluate habitat suitability, the program used the maximum entropy model. For MaxEnt operation, the maximum number of iterations was set to 10,000 , the convergence threshold to $10^{-5}$, and the number of replicates to 10 . The output format was logistic. A bootstrap run type and the "random seed" option were applied to provide random test partition (Phillips et al. 2006). To evaluate the results of the models, we used receiver operating characteristic (ROC) curves (Wang et al. 2007; Mas et al. 2013). Area under the curve (AUC) values lower than 0.6 meant that the result of the prediction was not much better than random, and a value of 1.0 indicated that the model prediction was excellent. We performed this procedure for the whole data set and subsequently separately for each of the three main groups of localities from the different parts of the species geographic range: (1) European (Peloponnese, PEL), (2) Turkish (Taurus, Anti-Taurus and Amanos mountains, AN), and (3) Lebanese (including Syrian and Israeli, LEB). The populations of $J$. drupacea from these three geographic regions exhibited significant genetic, morphological, and biochemical differentiations (Sobierajska et al. 2016; Adams et al. 2017). All predictions and the most important climatic variables were visualized in QGIS 2.14.21'Lyon' (QGIS Development Team 2012). The influence of particular environmental factors to the distribution of $J$. drupacea was verified using principal component analysis (PCA) implemented in R software.

\section{Results}

\section{Present geographic range}

The data allowed for an analysis of the relationship between the realized niche (Fig. 1) and recent climatic factors (Table 1). The important information from a geographic point of view was the altitudinal range of the species, which in Peloponnese appeared lower than in Turkey and in Lebanon (Fig. 2). Climatic factors related to the current distribution of $J$. drupacea are intercorrelated, frequently at statistically significant levels. The correlation of realized niche of $J$. drupacea with individual climate variables differed among the different regions of the species occurrence (Supplementary Materials, Table S2).

Evaluation of the MaxEnt model indicated that the realized niche prediction (Fig. 3a) for J. drupacea was very high. The average test AUC for the replicate runs was 0.980 for the whole range, 0.990 for Turkey, 0.992 for Europe, and 0.998 for Lebanon. The most important factor determining the current geographic range of $J$. drupacea was precipitation quantity in the coldest quarter (Table 1). This variable contributed $41 \%$ for the whole range of the species, $47.5 \%$ for PEL, and $26.7 \%$ for ANA, but interestingly, as much as $85.7 \%$ for LEB. Climate variables that contributed across the whole range were precipitation seasonality $(18.7 \%)$, precipitation in the warmest quarter $(9.6 \%)$, temperature seasonality $(9.5 \%)$, and mean temperature of the wettest quarter $(6.6 \%)$. For PEL, the second most important variable influencing the range prediction was temperature seasonality $(23.1 \%)$; however, precipitation seasonality $(11.1 \%)$ and precipitation in the driest month $(4.7 \%)$ were also relatively large contributing variables. For LEB, the most significant factor except for the precipitation in the coldest quarter was the precipitation in the wettest month (4.4\%). For AN, the mean temperature of the wettest quarter $(19.3 \%)$, the precipitation of the driest quarter $(14.9 \%)$, precipitation seasonality $(10.2 \%)$, and temperature seasonality $(9.6 \%)$ were all large contributing variables. Generally, temperature variables had a smaller impact on range relative to precipitation (Table 1).

Cartographic analysis indicated that $J$. drupacea had a broader potential than realized niche (compare Figs. 1 and 3a). Interestingly, when analyzed separately, climate conditions for each of the three parts of the geographic range (PEL, AN, and LEB) detected different areas with conditions potentially conducive for range expansion (Fig. 3). The analysis using climate conditions from AN found no area in PEL where the climate was suitable for $J$. drupacea (Fig. 3c). The analyses using parameters from the PEL and LEB localities found no suitable climate conditions outside of these two regions (Fig. 3b, d).

\section{Past and future geographic range}

Suitable climate conditions for J. drupacea colonization have changed drastically in the past. During the Riss-Würm (Eemian) interglacial about 130-115 ka BP, the species could theoretically only find favorable climate conditions in a restricted area close to the Mediterranean Sea in Turkey and substantially less suitable conditions prevailed on the Peloponnese in Europe and a narrow belt in the Lebanon mountains (Fig. 4a). Particularly favorable climate conditions for $J$. drupacea occurred during the LGM, ca $20 \mathrm{ka} \mathrm{BP}$, and provided an area for colonization almost three times as large as that available currently (Fig. 4b). By contrast, climate conditions in the mid-Holocene (about 6000 years BP) reduced the potential distributional area to one-third that currently available (Table 2).

Climate warming of $1{ }^{\circ} \mathrm{C}$ or $2{ }^{\circ} \mathrm{C}$ in the future will cause a reduction of the species' potential niche to $50 \%$ or $17 \%$, respectively, of the contemporary area (Fig. 4e, f and Table 2). 


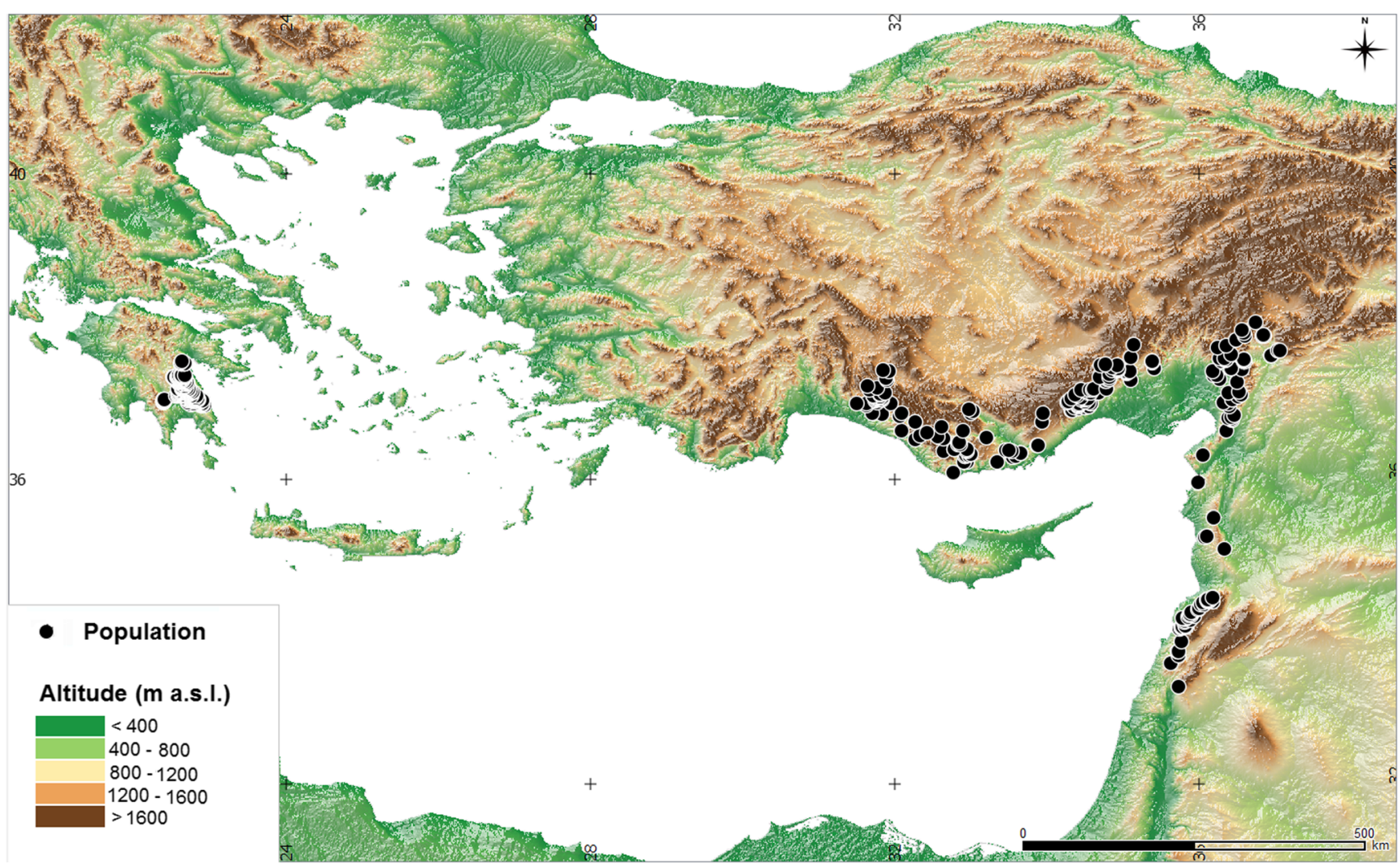

Fig. 1 Geographical distribution of Juniperus drupacea on the basis of georeferenced data (Supplementary Materials, Table 1)

Table 1 Contribution [\%] of bioclimatic variables and altitude for predicted habitat suitable for Juniperus drupacea on the data from the entire (ENT) and three different parts of the species geographic range: European (PEL), Turkish (AN) and Lebanese (LEB)

\begin{tabular}{|c|c|c|c|c|}
\hline Bioclimatic factor & ENT & PEL & AN & LEB \\
\hline BIO1 = Annual Mean Temperature & 0.1 & 0.0 & 0.0 & 0.0 \\
\hline $\mathrm{BIO} 2=$ Mean Diurnal Range $[$ Mean of monthly $(\max$ temp $-\min$ temp) $]$ & 0.1 & 0.1 & 0.4 & 0.0 \\
\hline $\mathrm{BIO} 3=$ Isothermality $(\mathrm{BIO} / \mathrm{BIO} 7)(* 100)$ & 1.2 & 0.4 & 1.4 & 0.1 \\
\hline BIO4 = Temperature Seasonality (standard deviation *100) & 9.5 & 23.1 & 9.6 & 0.1 \\
\hline BIO5 = Max Temperature of Warmest Month & 0.1 & 0.1 & 0.0 & 0.0 \\
\hline BIO6 = Min Temperature of Coldest Month & 0.2 & 0.1 & 0.0 & 0.0 \\
\hline BIO7 = Temperature Annual Range (BIO5-BIO6) & 0.4 & 0.4 & 0.4 & 0.1 \\
\hline BIO8 = Mean Temperature of Wettest Quarter & 6.6 & 0.0 & 19.3 & 0.2 \\
\hline BIO9 = Mean Temperature of Driest Quarter & 0.0 & 0.0 & 0.0 & 0.0 \\
\hline BIO10 = Mean Temperature of Warmest Quarter & 0.1 & 1.2 & 0.1 & 0.0 \\
\hline BIO11 = Mean Temperature of Coldest Quarter & 0.1 & 0.0 & 0.0 & 0.0 \\
\hline $\mathrm{BIO} 12=$ Annual Precipitation & 2.7 & 0.0 & 1.3 & 0.0 \\
\hline BIO13 = Precipitation of Wettest Month & 0.2 & 4.3 & 0.2 & 4.4 \\
\hline BIO14 = Precipitation of Driest Month & 0.4 & 4.7 & 5.0 & 2.0 \\
\hline BIO15 = Precipitation Seasonality (Coefficient of Variation) & 18.7 & 11.1 & 10.2 & 4.3 \\
\hline BIO16 = Precipitation of Wettest Quarter & 0.2 & 0.0 & 0.2 & 0.0 \\
\hline BIO17 = Precipitation of Driest Quarter & 0.5 & 0.0 & 14.9 & 1.1 \\
\hline BIO18 = Precipitation of Warmest Quarter & 9.6 & 2.7 & 7.1 & 0.4 \\
\hline BIO19 = Precipitation of Coldest Quarter & 41.0 & 47.5 & 26.7 & 85.7 \\
\hline Altitude & 5.6 & 4.0 & 3.2 & 1.6 \\
\hline
\end{tabular}


Fig. 2 Percent of georeferenced localities of Juniperus drupacea in the mountains of Turkey (AN), Lebanon (LEB), and Greece (PEL)

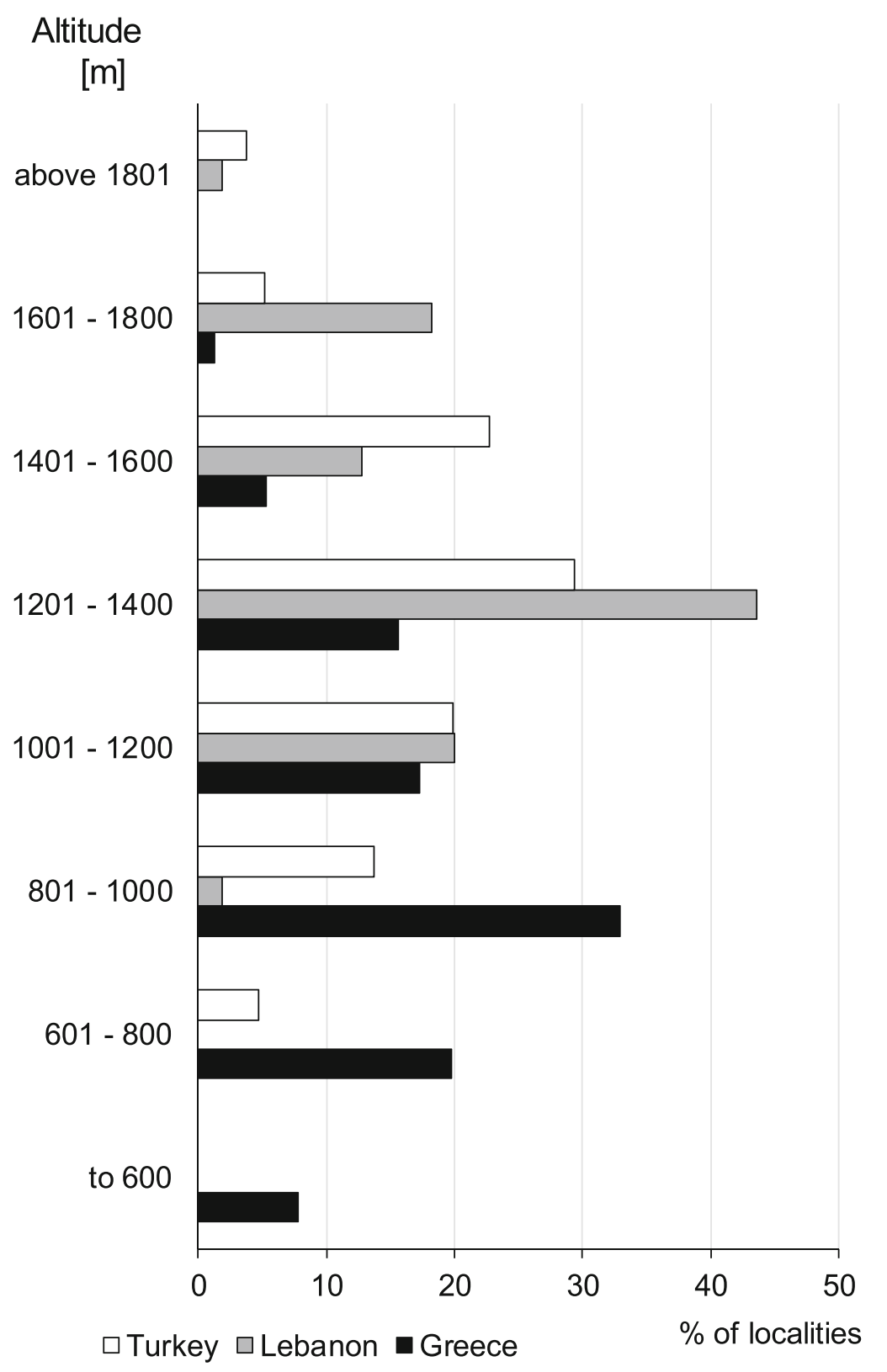

\section{Discussion}

\section{Geographic range}

The geographic range of $J$. drupacea was originally presented by Schmucker (1942). Coode and Cullen (1965) and Eliçin (1974) published the species' geographic range in Turkey and Lebanon in a simplified manner, but with localities marked on maps. Browicz (1982) published the first map highlighting the entire range of $J$. drupacea. Wazen and Fady (2015) redrew Browicz's (1982) map, adding the species' occurrence in northern Iraq. This latter locality is difficult to reconcile with the climatic conditions found there and was likely a misidentification (Blakelock 1966; Liu et al. 2018).

We believe that the map presented here (Fig. 1) is the most comprehensive and up to date. This map resulted from a wide range of data including historical information from classic herbarium collections and basic floras, verified data from new collections, and unpublished field notes. The highest elevation localities of the species in Europe were at 1790 m near Refugio Parnonas, while those at the lowest elevation were at $300 \mathrm{~m}$ below Moni Elonis, both in the Parnon Oros (Maerki 

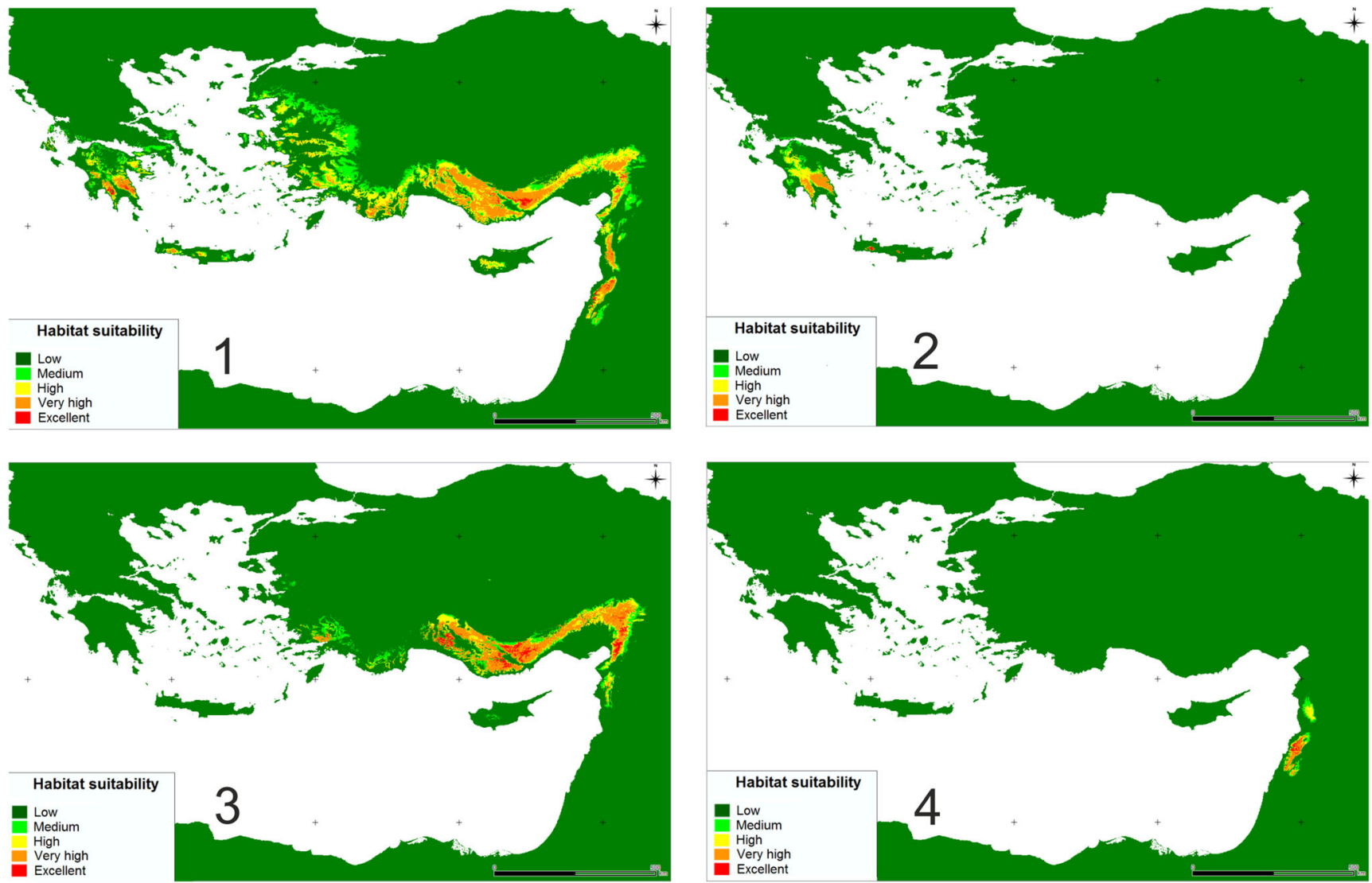

Fig. 3 Climate habitat suitability maps for the contemporary occurrence of Juniperus drupacea. a Data from the entire geographic range. b Data from European (PEL). c Data from Turkish (AN). d Data from Lebanese (including Syrian) (LEB) portions of the geographic range

and Frankis 2015). In Turkey, the highest elevation stands were recorded at $2050 \mathrm{~m}$ in Aladağlar (Schiechtl et al. 1965) and $2000 \mathrm{~m}$ in Ahır Dağ 1 , while the lowest elevation stand was reported at about 650-700 $\mathrm{m}$ (Kocakulak 2007). The prevalence of localities in Europe was between 800 and $1000 \mathrm{~m}$, while in Turkey and Lebanon, they were between 1200 and $1400 \mathrm{~m}$ (Fig. 2), which could be interpreted as indicating that optimal conditions in the Asiatic mountains were at a higher altitude. These data were consistent with the work of AbiSaleh et al. (1996) who found that the optimal altitudinal range of the species in Lebanon was 1250-1500 m.

\section{Climatic determinants of geographic range}

From the 19 verified factors relating to climate conditions, precipitation in the coldest 3 months appeared to be the most influential with regard to the realized niche of $J$. drupacea. Surprisingly, temperature variables, which are very influential to the geographic ranges of most organisms (Bradie and Leung 2017), played only a limited role in the Syrian juniper distribution (Supplementary Materials, Fig. S1). The weak influence of temperature may in part result from a high level of adaptation by the species to a broad range of temperatures, with high diurnal and annual amplitudes. From the range of variables relating to temperature, only mean temperature in the wettest quarter and temperature seasonality had an influence on the species' realized niche, and even so, the dependence was not as strong as for the precipitation variables (Table 1).

Average climate conditions across the geographic range of $J$. drupacea were characterized by relatively high precipitation during the coldest quarter (the winter months of December-February), which was frequently associated with snow that could sometimes be intense but not persistent. Snow cover can last up to a few weeks in localities above $1000 \mathrm{~m}$ in the Parnon Oros on Peloponnese and above $1200-1300 \mathrm{~m}$ in the Taurus and Lebanon mountains (Türkeș 2003; Lionello 2012; Atalay et al. 2014). The total precipitation for the coldest 3 months was usually 400 $500 \mathrm{~mm}$ and sometimes up to $600 \mathrm{~mm}$ (Fig. 5). Precipitation during the driest months was also a positive influence on the geographic range of the Syrian juniper in Turkey. There was high interannual variability in precipitation during the summer months (Thompson 2005; Lionello 2012; Atalay et al. 2014), and while there was on average $100-150 \mathrm{~mm}$ annually, there was more than $200 \mathrm{~mm}$ in some years. Regions with a more continental type of the climate in Turkey, where precipitation seasonality and 


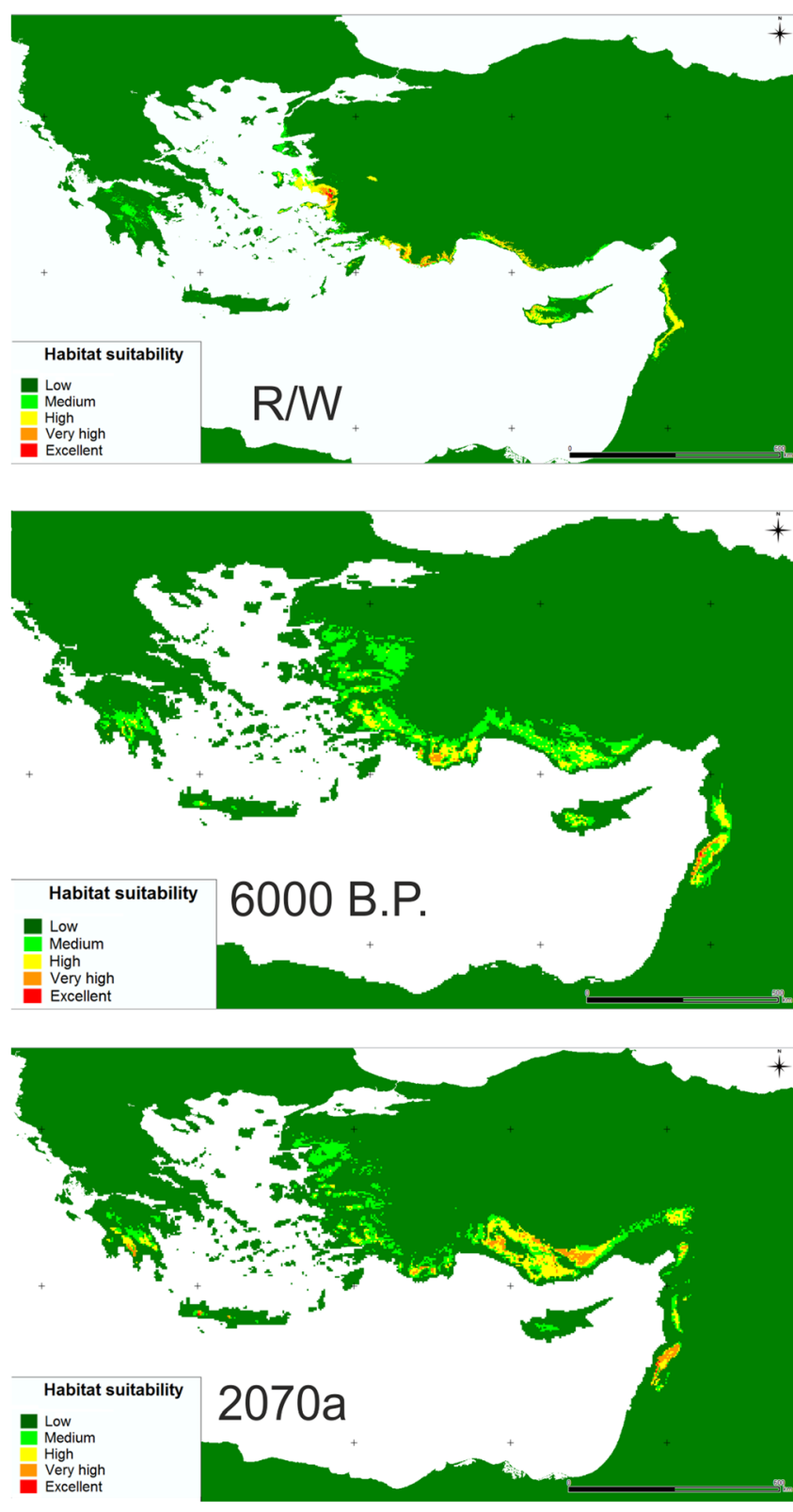

Fig. 4 Climatically suitable habitat maps for Juniperus drupacea. a During the Eemian about 125 ka BP. b During the Late Glacial Maximum about $20 \mathrm{ka}$ BP. c During the Holocene climate optimum
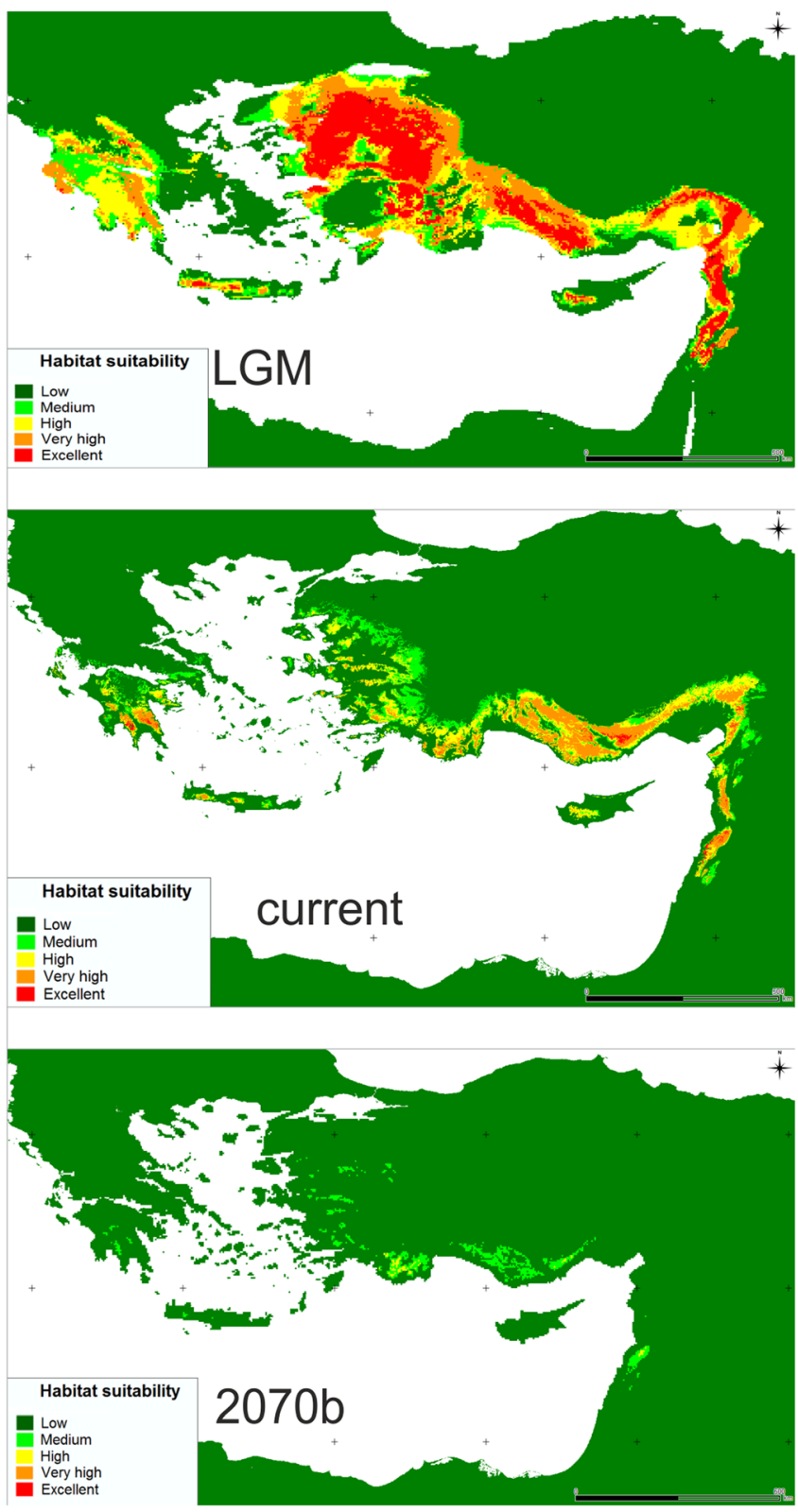

about 6000 BP. d In current climate conditions. e In 2070 for low climate warming $\left(2.6 \mathrm{~W} \mathrm{~m}^{-2}\right)$. f In 2070 for high climate warming $\left(8.5 \mathrm{~W} \mathrm{~m}^{-2}\right)$

Table 2 Estimated area of potential distribution of Juniperus drupacea.

\begin{tabular}{lll}
\hline Model & Predicted area $\left(\mathrm{km}^{2}\right)$ & Difference with respect to the present $\left(\mathrm{km}^{2}\right.$ and \%) \\
\hline Present & 103301 & - \\
Eemian interstadial about $130 \mathrm{ka} \mathrm{BP}$ & 21670 & $81631(-79 \%)$ \\
Late Glacial Maximum about $20 \mathrm{ka} \mathrm{BP}$ & 286395 & $183094(+177 \%)$ \\
Holocene climate optimum about $6 \mathrm{ka} \mathrm{BP}$ & 68908 & $34393(-33 \%)$ \\
Future - low climate warming $\left(2.6 \mathrm{~W} / \mathrm{m}^{2}\right)$ & 54975 & $54975(-47 \%)$ \\
Future - higher climate warming $\left(8.5 \mathrm{~W} / \mathrm{m}^{2}\right)$ & 17286 & $86015(-83 \%)$ \\
\hline
\end{tabular}


Emberger's quotients have lower values, do not have $J$. drupacea (compare Figs. 1 and 5).

The greater aridity in the Eastern part of the Peloponnese compared with the mountains of Turkey (Türkeș 2003; Ünal et al. 2003; Panagiotis et al. 2013; Paparrizos et al. 2016) did not seem to influence the species' geographic range; however, it did affect absolute numbers, with just single dead individuals of $J$. drupacea observed on the shallow soil (Maerki, personal communication).

The impact of high precipitation seasonality and low precipitation during summer months on $J$. drupacea distribution may be diminished in the Taurus Mountains by mist at elevations of about 1000-1200 m (Atalay et al. 2014). The effect of mist in the mountains may be comparable to the beneficial influence of mistiness on the northern slopes of the Rif Mountains in northern Africa on the occurrence of Abies marocana Trab. (Esteban et al. 2010) and Taxus baccata L. (Romo et al. 2017). However, both of these species are more susceptible to a lack of humidity than $J$. drupacea. Though, J. drupacea is somewhat more drought resistant, which explains its distribution and occurrence in moderately thermophilic plant communities (Zohary 1973;

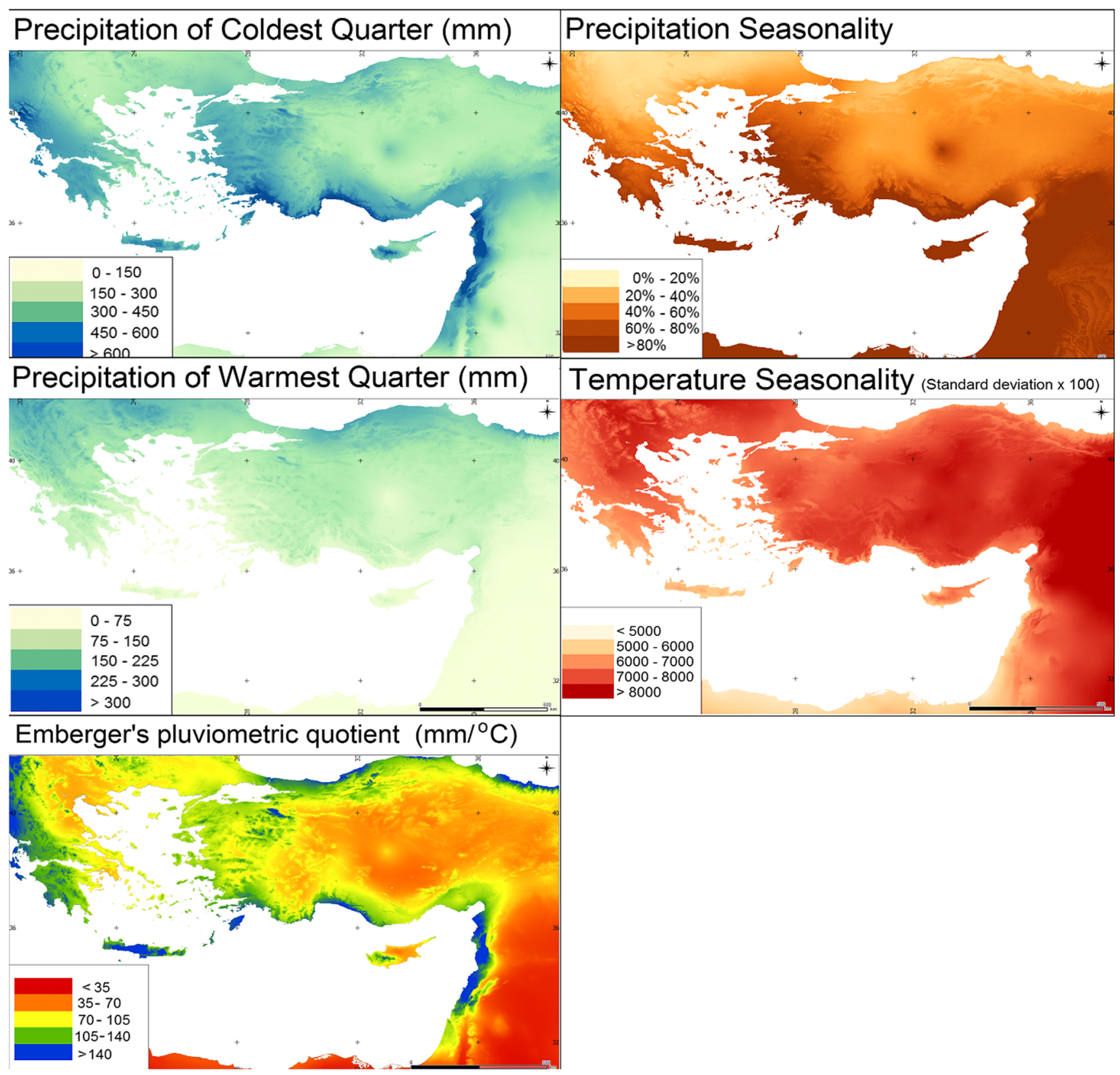

Fig. 5 Distribution of the bioclimatic variables with the greatest degree of influence on the occurrence of Juniperus drupacea 
Mayer and Aksoy 1986; Talhouk et al. 2001; Bergmeier 2002; Atalay et al. 2014).

Juniperus drupacea occurred in the oro-Mediterranean climate with high precipitation during the cold months. The temperature during these months did not generally exceed $5-6{ }^{\circ} \mathrm{C}$ (Fig. 5c) and on some days could drop to $-5{ }^{\circ} \mathrm{C}$ or even $10{ }^{\circ} \mathrm{C}$ (Orcan et al. 2004, p. 310; Bakker et al. 2013, p. 63). Conversely, during the dry period (June to August), the average temperature reached $20-21{ }^{\circ} \mathrm{C}$ (Quézel and Médail 2003; Orcan et al. 2004; Rivas-Martínez et al. 2004; Giannakopoulos et al. 2009; Lionello 2012; Atalay et al. 2014: 795; Robinson et al. 2006; Roberts et al. 2011). In spite of that, temperatures only influenced the current geographic range of the species to a limited extent (Table 1). Among temperature variables, the most influential was the mean temperature of the wettest quarter, which for the area of J. drupacea occurrence was the coldest quarter, December-February. It was noteworthy that low temperatures combined with the lower precipitation above the cloud level appeared as a restricting factor for the species' occurrence in the high mountains.

The European, Turkish, and Lebanese populations evolved in slightly different climatic conditions (Table 1). The separate analysis of the conditions for the European part of the geographic range of $J$. drupacea did not detect suitable conditions in any other part of the current species geographic range, but did indicate highly propitious climatic conditions in the mountains of Crete. Similarly, the climate conditions analyzed for the Lebanese part of species range did not find other suitable areas in Anatolia or in Europe (Fig. 3). Different climate conditions in different parts of a geographic range containing different genetic lineages were also detected for the lizard Phrynosoma platyrhinos (Jezkova et al. 2016), for rodents from the genus Nephelomys Thomas (Anderson and Raza 2010), and for Cornus florida L. (Call et al. 2016). This was interpreted as resulting from different niches in the past and due to spatial isolation within different parts of the geographic range. Subsequent genetic comparisons detected differences between subranges of both, Phrynosoma platyrhinos and Nephelomys (Anderson and Raza 2010; Jezkova et al. 2016).

Species niche modeling is affected by parameterization with only a partial distribution as was shown, for example, with the Carbonell's wall lizard (Podarcis carbonelli Perez Mellado; Carretero and Sillero 2016). The distribution of $P$. carbonelli is elongated, scattered, and divided into four parts. An analysis of niche conditions for the central part of the geographic range allowed the prediction of the entire distributional area; however, this was not possible when using information from the three other parts (Carretero and Sillero 2016). In our study, no niche in the three verified parts of $J$. drupacea's geographic range allowed the prediction of the entire distribution of the species. Even the largest (AN subrange) predicted only the Turkish niches and parts of the Syrian niches (Fig. 3). Consequently, the adaptation of
European, Turkish, and Lebanese populations to local climates was at least part of the reason for the genetic and morphological differentiation detected by Sobierajska et al. (2016) and by Adams et al. (2017). These populations are considered independent biogeographic units.

\section{Past and future geographic range}

The site conditions of Syrian juniper localities allowed the classification of the species as tolerating average monthly temperatures of $0-22{ }^{\circ} \mathrm{C}$ (Hijmans et al. 2005), but it did not respond in a significant way to lower extremal daily temperatures (Table 1). Despite higher precipitation, its ecological characteristics probably allowed it to survive in Anatolia during the last interglacial in some areas, likely a result of higher insolation (Abrantes et al. 2012, but see also discussion in BarMatthews et al. 1997 and Cheddadi and Khater 2016).

Direct use of palynological data for reconstructing $J$. drupacea's geographic range is impossible because the pollen grains of juniper species are indistinguishable (e.g., Carrión et al. 2001). However, J. drupacea distribution contemporary follows Cedrus libani, so the pollen of cedar could also indicate the presence of Syrian juniper during the LGM or at least at the Late Glacial (e.g., Vermoere et al. 1999; Hajar et al. 2010; Touchan et al. 2014; Cheddadi and Khater 2016), which coincides with our result (Fig. 4b). There may have even been compensatory factors, such as a reduction in broadleaved tree occurrence to small patchy areas that could have reduced light competition and resulted in a broader distribution of $J$. drupacea (e.g., Carrión et al. 2001; Carrión 2002; but see also the percentage of Quercus pollen in Vermoere et al. 1999).

Considering the current thermal conditions at the upper altitudinal limit of $J$. drupacea together with the temperature lapse rate in the mountains $\left(6.5^{\circ} \mathrm{C} \mathrm{km}^{-1}\right.$, Barry and Chorley 1987) during LGM, the species would have had appropriate thermal conditions for growth at altitudes of about 1200 $1400 \mathrm{~m}$ lower than at present. Consequently, its geographic range could have covered a larger area (Dean et al. 2015). The area where $J$. drupacea occurred in the Taurus Mountains after the LGM, even during the first millennia of the Holocene, could also have been somewhat below the present altitudinal range because of the prolonged deglaciation of the highest parts of the mountains (Sarkaya et al. 2011).

The response of $J$. drupacea tree-ring increments to climate conditions would be interesting, but has not yet been analyzed. However, the co-occurrence of this species with Cedrus libani, Abies cilicica, Pinus nigra, and A. cephalonica suggests that it would respond similarly to climatic changes. Cedrus libani, Abies cilicica, Pinus nigra, and A. cephalonica are included into a group of species that react positively to May-June precipitation (Touchan et al. 2014), which was detected as important for $J$. drupacea, though mostly for the 
Anatolian portion of its geographic range (BIO17 and BIO18 in Table 1).

During the Holocene climate optimum about 6000 years ago, higher temperatures, but also higher precipitation, shifted the area with climate conditions suitable for $J$. drupacea to the higher altitudes (Fig. 4c). We should expect an even greater restriction on the species occurrence though due to the expansion of forest-forming broadleaved trees, primarily oaks, which influence junipers through light competition (Carrión 2002). Juniperus drupacea, as other juniper species, likely escaped from lower locations to higher altitudes or other places inaccessible to broadleaved trees, such as steep slopes, rocks, and rocky ridges. However, this is only a working hypothesis with no confirmatory paleo data.

The effect of future climate conditions depends on the scenario. While a $1{ }^{\circ} \mathrm{C}$ temperature increase (scenario RCP2.6) would dramatically reduce the area with conditions suitable for $J$. drupacea, conservation of the species genetic variation in situ would still be ensured. By contrast with a $2{ }^{\circ} \mathrm{C}$ increase (scenario RCP8.5), the species would not find suitable conditions in most of its current geographic range (compare Fig. $4 \mathrm{f}$ and Fig. 1), due in part to higher temperatures, but also due to less precipitation and greater evapotranspiration (Lionello 2012).

\section{Threats}

Precipitation is a crucial factor for many Mediterranean tree species (Thompson 2005; Allen et al. 2010). Unfortunately, this region is threatened by droughts in the future. Precipitation in the coldest quarter may be reduced by 15$25 \%$ within J. drupacea's range (Giorgi and Lionello 2008). This variable was identified as the most important for the species, and such extensive drying in a short time will pose a great threat to natural populations. The lack of rain during the growing season additionally deepens the water deficit and increases fire risk. These effects were observed in recent years, when after long periods without rain, the death of individual trees was observed in the locations with shallow soils (Maerki, personal communication).

The Anti-Taurus Mountains with their broad distribution of $J$. drupacea may lose conditions suitable for the species. The Anti-Taurian populations differ genetically from all the others in Turkey (Sobierajska et al. 2016) and therefore, the loss of this population will diminish species variation. Populations from the Turkish portion of the species' geographic range should be monitored carefully despite the lack of a current threat. Surprisingly, the most conducive climate conditions will be retained in a small area of the Lebanon Mountains. In the Peloponnese, the current major threat for $J$. drupacea is fire. Elevated temperatures could increase the fire risk substantially.

The scattered populations of $J$. drupacea, especially in regions with fragmented forests, may be endangered due to a lack of pollination and fertilization, leading to production of empty seeds. This problem was detected in other dioecious junipers (Juan et al. 2003; Tylkowski 2009, 2010; Rodríguez-Garcia et al. 2017). Moreover, the presence of a reserve of dormant seeds in the soil (Owens and Schliesing 1995) that can stabilize population dynamics by spreading out risk and diminishing large fluctuations in response to shortterm environmental perturbations (Leishman et al. 2000) is threatened by climate change. Litter decomposition and the organisms involved in this key process are also affected by drought (Kinloch and Friedel 2005; Li et al. 2017).

There is a necessity to conserve the widest possible range of genetic diversity considering that $J$. drupacea is an exceptional relict species within the genus. The populations from the Peloponnese, different parts of the Taurus in Turkey, and the Syria and the Lebanon mountains should be preserved in the form of conservation plantations and seed orchards. Additionally, the biology of seed dormancy requires further study in order to use the species in forest restoration programs, and in particular taking into consideration the gender balance. Ex situ conservation of seeds should also be developed. As of 2019, such species conservation activities have not been initiated; however, J. drupacea is planted as a forest tree in Turkey (Tolga Ok, personal communication). In Lebanon, some efforts were made to limit dye back of $J$. drupacea resulting from Arceuthobium oxycedri M. Bieb. infestation and to propagate the species vegetatively within a program that plans to plant 40 million trees (Magda Bou Dagher, personal communication).

Acknowledgements The authors would like to acknowledge the Cupressus Conservation Project and all those who provided information on J. drupacea localities.

Funding information The study was financially supported by the Institute of Dendrology of the Polish Academy of Sciences, Kórnik, Poland, and by the Polish Ministry of Science under grant no. NN303 153037.

Open Access This article is distributed under the terms of the Creative Commons Attribution 4.0 International License (http:// creativecommons.org/licenses/by/4.0/), which permits unrestricted use, distribution, and reproduction in any medium, provided you give appropriate credit to the original author(s) and the source, provide a link to the Creative Commons license, and indicate if changes were made.

\section{References}

Abi-Saleh B, Nazih N, Hanna R, Safi N, Safi S, Tohmé H (1996) Etude de la diversité biologique du Liban. Flore Terrestre 3. MOA-UNEP, Beyrouth

Abrantes F, Voelker AHL, Sierro FJ, Naughton N, Rodrigues T, Cacho I, Aritzegui D, Brayshaw D, Sicre M-A, Batista L (2012) Paleoclimate variability in the Mediterranean region. In: Lionello P (ed) The climate of the Mediterranean region. From the past to the future. Elsevier, Amsterdam, pp 1-86. https://doi.org/10.1016/C2011-0-06210-5 
Adams RP (2014) Junipers of the world: the genus Juniperus, 4th edn. Trafford, Bloomington

Adams RP, Boratyński A, Bou Dagher Kharrat M, Leschner HV, Mataraci T, Schwarzbach AE (2017) Geographic variation in Juniperus drupacea: DNA sequencing and volatile leaf oils: further evidence of putative Pleistocene genetic isolation between Europe and Asia. Phytologia 99(2):249-257

Allen CD, Macalady AK, Chenchouni H, Bachelet D, McDowell N, Vennetier M, Kitzberger T, Rigling A, Breshears DD, Hogg EH, Gonzalez P, Fensham R, Zhang Z, Castro J, Demidova N, Lim JH, Allard G, Running SW, Semerci A, Cobb N (2010) A global overview of drought and heat-induced tree mortality reveals emerging climate change risks for forests. For Ecol Manag 259:660-684. https://doi.org/10.1016/j.foreco.2009.09.001

Al-Qaddi N, Vessella F, Stephan J, Al-Eisawi D, Schirone B (2017) Current and future suitability areas of kermes oak (Quercus coccifera L.) in the Levant under climate change. Reg Environ Chang 17:143-156. https://doi.org/10.1007/s10113-016-0987-2

Anderson RP, Raza A (2010) The effect of the extent of the study region on GIS models of species geographic distributions and estimates of niche evolution: preliminary tests with montane rodents (genus Nephelomys) in Venezuela. J Biogeogr 37:1378-1393. https://doi. org/10.1111/j.1365-2699.2008.02051.x

Atalay I, Efe R, Öztürk M (2014) Ecology and classification of forests in Turkey. Procedia Soc Behav Sci 120:788-805. https://doi.org/10. 1016/j.sbspro.2014.02.163

Awad L, Fady B, Khater C, Roig A, Cheddadi R (2014) Genetic structure and diversity of the endangered fir tree of Lebanon (Abies cilicica Carr.): implications for conservation. PLoS ONE 9:e90086. https:// doi.org/10.1371/journal.pone.0090086

Bakker J, Paulisse E, Kaniewski D, Poblome J, Verstaeten G, Waelkens M (2013) Climate, people, fire and vegetation: new insights into vegetation dynamics in the Eastern Mediterranean since the 1st century AD. Clim Past 9:57-87. https://doi.org/10.5194/cp-9-57-2013

Bar-Matthews M, Ayalon A, Kaufman A (1997) Late Quaternary paleoclimate in the Eastern Mediterranean region from stable isotope analysis of speleothems at Soreq Cave, Israel. Quat Res 47: 155-168. https://doi.org/10.1006/qres.1997.1883

Barry RG, Chorley RJ (1987) Atmosphere, weather, and climate, 5th edn. Methuen, New York

Bergmeier E (2002) Plant communities and habitat differentiation in the Mediterranean coniferous woodlands of Mt. Parnon (Greece). Folia Geobot 37:309-331. https://doi.org/10.1007/BF02805214

Blakelock RA (1966) Cupressaceae. In: Townsend CC, Guest E (eds) Flora of Iraq 2. Glasgow University Press, Glasgow, pp 89-95

Boratyński A, Browicz K (1982) Juniperus drupacea in Greece. Arbor Kórn 27:3-16

Bradie L, Leung B (2017) A quantitative synthesis of the importance of variables used in MaxEnt species distribution models. J Biogeogr 44:1344-1361. https://doi.org/10.1111/jbi.12894

Browicz K (1982) Chorology of trees and shrubs in South-West Asia and adjacent regions, 1. Polish Academy of Science, Poznań

Call A, Sun YX, Yu Y, Pearman PB, David DT, Trigiano RN, Carbone I, Xiang Q-YL (2016) Genetic structure and post-glacial expansion of Cornus florida L. (Cornaceae): integrative evidence from phylogeography, population demographic history, and species distribution modelling. J Syst Evol 54:136-151. https://doi.org/10. $1111 /$ jse. 12171

Carretero MA, Sillero N (2016) Evaluating how species niche modelling is affected by partial distribution with an empirical case. Acta Oecol 77:207-216. https://doi.org/10.1016/j.actao.2016.08.014

Carrión JS (2002) Patterns and process of Late Quaternary environmental change in a montane region of southwestern Europe. Quat Sci Rev 21:2047-2066. https://doi.org/10.1016/S0277-3791(02)00010-0

Carrión JS, Andrade A, Bennett KD, Navarro C, Munuera M (2001) Crossing forest thresholds: inertia and collapse in a Holocene sequence from south-central Spain. Holocene 11:635-653. https:// doi.org/10.1191/09596830195672

Case MJ, Lawler JJ (2017) Integrating mechanistic and empirical model projections to assess climate impacts on tree species distributions in northwestern North America. Glob Chang Biol 23:2005-2015. https://doi.org/10.1111/gcb.13570

Cheddadi R, Khater C (2016) Climate change since the last glacial period in Lebanon and the persistence of Mediterranean species. Quat Sci Rev 150:146-157. https://doi.org/10.1016/j.quascirev.2016.08.010

Cheddadi R, Fady B, François L, Hajari L, Suc JP, Huang K, Demarteau M, Vendramin GG, Ortu E (2009) Putative glacial refugia of Cedrus atlantica deduced from Quaternary pollen records and modern genetic diversity. J Biogeogr 36:1361-1371. https://doi.org/10.1111/j. 1365-2699.2008.02063.x

Christensen KI (1997) Juniperus L. In: Strid A, Tan K (eds) Flora Hellenica, 1. Koelz, Königstein, pp 10-14

Collins M, Knutti R, Arblaster J, Dufresne JL, Fichefet T, Friedlingstein P, Gao X, Gutowski WJ, Johns T, Krinner G, Shongwe M, Tebaldi C, Weaver AJ, Wehner M (2013) Long-term climate change: projections, commitments and irreversibility. In: Stocker TF, Qin D, Plattner GK, Tignor M, Allen SK, Boschung J, Nauels A, Xia Y, Bex V, Midgley PM (eds) Climate change 2013: the physical science basis. Contribution of Working Group I to the Fifth Assessment Report of the Intergovernmental Panel on Climate Change. Cambridge University Press, Cambridge and New York, pp 1029-1136

Coode MJE, Cullen J (1965) Juniperus L. In: Davis PH (ed) Flora of Turkey, 1. Edinbourgh University Press, Edinbourgh, pp 78-84

Dean JR, Jones MD, Leng MJ, Noble SR, Metcalfe SE, Sloane HJ, Sahy D, Eastwood WJ (2015) Eastern Mediterranean hydroclimate over the late glacial and Holocene. Reconstructed from the sediments of Nar lake, central Turkey, using stable isotopes and carbonate mineralogy. Quat Sci Rev 124:162-174. https://doi.org/10.1016/j. quascirev.2015.07.023

Douaihy B, Vendramin GG, Boratyński A, Machon N, Bou DagherKharrat M (2011) Genetic variation and population structure of Juniperus excelsea M.-Bieb. in the east Mediterranean region. AOB Plants 2011:plr003. https://doi.org/10.1093/aobpla/plr003

Douaihy B, Sobierajska K, Jasińska AK, Boratyńska K, Ok T, Romo A, Machon N, Didukh YA, Bou Dagher-Kharrat MB, Boratyński A (2012) Morphological versus molecular markers to describe variability in Juniperus excelsa subsp. excelsa (Cupressaceae). AOB Plants 2012:pls013. https://doi.org/10.1093/aobpla/pls013

Douaihy B, Restoux G, Machon N, Bou Dagher-Kharrat M (2013) Ecological characterization of the Juniperus excelsa stands in Lebanon. Ecol Mediterr 39:169-180

Douaihy B, Tarraf P, Stephan J (2017) Juniperus drupacea Labill. stands in Jabal Moussa Biosphere Reserve, a pilot study for management guidelines. Plant Sociol 54(Suppl 1):39-45. https://doi.org/10.7338/ pls2017541S1/06

Eastwood WJ (2004) East Mediterranean vegetation and climate change. In: Griffiths HI, Kryštufek B, Reed JM (eds) Balkan biodiversity. Kluwer, Dortrecht, $\mathrm{p}$ 2548. https://doi.org/10.1007/978-1-4020-2854-0

Eliçin G (1974) Étude anatomique chez Arceuthos drupacea Ant. et Kotschy et son aire naturelle en Turquie. Istanbul Üniversitesi Orman Fakültesi Dergisi A 24(2):194-208

Eliçin G (1977) Türkiye doğal ardiç (Juniperus L.) taksonlarının yayılıșları ile önemli morfolojik ve anatomik özellikleri üzerinde araștırmalar. İstanbul Üniversitesi, Orman Fakültesi Yayınları, İstanbul, 2327/232

Emberger L (1955) Une classification biogéographique des climats. Rech Trav Lab Bot Fac Sci Montpellier Sér Bot 7:3-43

Esteban LG, Palacios P, Rodríguez-Losada Aguado L (2010) Abies pinsapo forests in Spain and Morocco: threats and conservation. Oryx 44:276-284. https://doi.org/10.1017/S0030605310000190

Fady B, Lefèvre F, Vendramin GG, Ambert A (2008) Genetic consequences of past climate and human impact on Eastern Mediterranean Cedrus 
libani forests. Implications for their conservation. Conserv Genet 9:8595. https://doi.org/10.1007/s10592-007-9310-6

Farjon A (2005) A monograph of Cupressaceae and Sciadopitys. Royal Botanic Gardens, Kew

Gardner M (2013) Juniperus drupacea. The IUCN Red List of Threatened Species 2013: e.T30311A2792553. https://doi.org/10. 2305/IUCN.UK.2013-1.RLTS.T30311A2792553.en

Gardner M (2017) Juniperus drupacea. The IUCN Red List of Threatened Species 2017: e.T30311A83932989. https://doi.org/10. 2305/IUCN.UK.2013-1.RLTS.T30311A2792553.en

Gaussen H (1968) Les Gymnospermes actuelles et fossiles, fascicle 10, Les Cuppressacées. Centre National de la Recherche Scientifique, Faculté des Sciences de Toulouse, Toulouse

Gent PR, Danabasoglu G, Donner LJ, Holland MM, Jayne SR, Lawrence DM, Neale RB, Rasch PJ, Vertenstein M, Worley PH, Yang ZL, Zhang MH (2010) The community climate system model version 4. J Clim 24:4973-4991. https://doi.org/10.1175/2011JCLI4083.1

Giannakopoulos C, Le Sager P, Bindi M, Moriondo M, Kostopoulou E, Goodess CM (2009) Climatic changes and associated impacts in the Mediterranean resulting from a $2^{\circ} \mathrm{C}$ global warming. Glob Planet Chang 68:209-224. https://doi.org/10.1016/j.gloplacha.2009.06.001

Giorgi F, Lionello P (2008) Climate change projections for the Mediterranean region. Glob Planet Chang 63:90104-90104. https://doi.org/10.1016/j.gloplacha.2007.09.005

Hajar L, Khater C, Cheddadi R (2008) Vegetation changes during the late Pleistocene and Holocene in Lebanon: a pollen record from the Bekaa Valley. Holocene 18:1089-1099. https://doi.org/10.1177/ 0959683608095580

Hajar L, François L, Khater C, Jomaa I, Déqué M, Cheddadi R (2010) Cedrus libani (A. Rich) distribution in Lebanon: past, present and future. C R Biol 333:622-630. https://doi.org/10.1016/j.crvi.2010.05.003

Hewitt GM (2004) Genetic consequences of climatic oscillations in the Quaternary. Philos Trans R Soc B 359:183-195. https://doi.org/10. 1098/rstb.2003.1388

Hijmans RJ, Cameron SE, Parra JL, Jones PG, Jarvis A (2005) Very high resolution interpolated climate surfaces for global land areas. Intern J Clim 25:1965-1978. https://doi.org/10.1002/joc.1276

Jezkova T, Jaeger JR, Oláh-Hemmings V, Jones KB, Lara-Resendiz RA, Mulcahy DG, Riddle BR (2016) Range and niche shifts in response to past climate change in the desert horned lizard Phrynosoma platyrhinos. Ecography 39:437-448. https://doi.org/10.1111/ecog.01464

Juan R, Pastor J, Fernández I, Diosdado JC (2003) Relationships between mature cone traits and seed viability in Juniperus oxycedrus 1. subsp. macrocarpa (Sm.) Ball (Cupressaceae). Acta Biol Cracov Ser Bot 45:69-78

Karaca H (1994) Monumental trees of Turkey: 6. Juniperus drupacea. Karaca Arbor Mag 2:135-136

Kinloch JE, Friedel MH (2005) Soil seed reserves in arid grazing lands of central Australia. Part 1: seed bank and vegetation dynamics. J Arid Environ 60:133-161. https://doi.org/10.1016/j.jaridenv.2004.03.005

Kocakulak E (2007) Juniperus drupacea Lab. uçucu yağı üzerinde araștırmalar (research on Juniperus drupacea Lab. oil). T.C. Gazi Üniversitesi, Sağlık Bilimleri Enstitüsü, Farmakognozi Anabilim Dal1, Ankara (Gazi University, Health Sciences Institute, Pharmacognosis Dept. PhD thesis) (in Turkish)

Kvaček Z (2002) A new juniper from the Paleogene of Central Europe. Fed Repert 113:492-502. https://doi.org/10.1002/fedr.200290001

Leishman MR, Wright IJ, Moles AT, Westoby M (2000) The evolutionary ecology of seed size. In: Fenner M (ed) Seeds: the ecology of regeneration in plant communities. CAB International, Wallingford, pp 31-57. https://doi.org/10.1079/9780851994321.0000

Li C, Xiao B, Wang Q, Zheng R, Wu J (2017) Responses of soil seed bank and vegetation to the increasing intensity of human disturbance in a semi-arid region of northern China. Sustainability 9(1837):113. https://doi.org/10.3390/su9101837
Lionello P (2012) The climate of the Mediterranean region. From the past to the future. Elsevier, Amsterdam. https://doi.org/10.1016/C20110-06210-5

Liu C, White M, Newell G (2018) Detecting outliers in species distribution data. J Biogeogr 45:164-176. https://doi.org/10.1111/jbi.13122

Maerki D, Frankis MP (2015) Juniperus drupacea in the Peloponnese (Greece). Trip report and range map, with notes on phenology, phylogeny, palaeontology, history, types and use. Bull Cupressus Conserv Proj 3(3):3-31 http://www.cupressus.net/bulletin/08/ JUdrupaceaText M Pekmez.doc and http://www.cupressus.net/ bulletin/08/JUdrupaceaPhotos.pdf. Accessed 11.06.2015

Mao K, Hao G, Liu J, Adams RP, Milne RI (2010) Diversification and biogeography of Juniperus (Cupressaceae): variable diversification rates and multiple intercontinental dispersals. New Phytol 188:254 272. https://doi.org/10.1111/j.1469-8137.2010.03351.x

Mas JF, Soares Filho B, Pontius RG, Farfán Gutiérrez M, Rodrigues H (2013) A suite of tools for ROC analysis of spatial models. ISPRS Intern J Geo-Inform 2:869-887. https://doi.org/10.3390/ijgi2030869

Mayer H, Aksoy U (1986) Wälder der Türkei. Fischer, Stuttgart-New York

Médail F, Diadema K (2009) Glacial refugia influence plant diversity patterns in the Mediterranean Basin. J Biogeogr 36:1333-1345. https://doi.org/10.1111/j.1365-2699.2008.02051.x

Mouterde P (1966) Nouvelle flore du Liban et de la Syrie, 1. Éditions de l'Imprimerie Catholique, Beyrouth

Orcan N, Binzet R, Yaylalığlu E (2004) The flora of Fındıkpınarı (Mersin-Turkey) Plataeu. Flora Mediterr 14:309-345

Orland IJ, Bar-Matthews M, Ayalon A, Matthews A, Kozdon R, Ushikubo T, Valley JW (2012) Seasonal resolution of Eastern Mediterranean climate change since $34 \mathrm{ka}$ from a Soreq Cave speleothem. Geochim Cosmochim Acta 89:240-255. https://doi. org/10.1016/j.gca.2012.04.035

Otto-Bliesner BL, Marshall SJ, Overpeck JT, Miller GH, Hu A, Members CLIP (2006) Simulating Arctic climate warmth and icefield retreat in the last interglaciation. Science 311:1751-1753. https://doi.org/ 10.1126/science. 1120808

Owens MK, Schliesing TG (1995) Invasive potential of ashe juniper after mechanical disturbance. J Range Manag 48:503-507. https://doi. org/10.2307/4003060

Özkan K, Özdemir Ș, Mert A, Negiz MG (2015) Modeling and mapping potential distribution of Crimean juniper (Juniperus excelsa Bieb.) using correlative approaches. J Environ Biol 36:9-15

Palamarev E (1989) Paleobotanical evidences of the Tertiary history and origin of the Mediterranean sclerophyll dendroflora. Plant Syst Evol 162:93-107. https://doi.org/10.1007/BF00936912

Palamarev E, Bozukov V, Uzunova K, Petkova A, Kitanov G (2005) Catalogue of the Cenozoic plants of Bulgaria (Eocene to Pliocene). Phytol Balkan 11:215-364

Panagiotis TN, Politi N, Kapsomenakis J (2013) Spatial and temporal variability of the aridity index in Greece. Atmos Res 119:140-152. https://doi.org/10.1016/j.atmosres.2011.06.017

Paparrizos S, Maris FP, Matzarakis A (2016) Integrated analysis and mapping of aridity over Greek areas with different climate conditions. Glob NEST J 18:131-145. https://doi.org/10.30955/gnj.001775

Phillips SJ, Anderson RP, Schapire RE (2006) Maximum entropy modeling of species geographic distributions. Ecol Model 190:231-259. https://doi.org/10.1016/j.ecolmodel.2005.03.026

QGIS Development Team (2012) QGIS geographic information system. Open Source Geospatial Foundation Project. URL http:/qgis.osgeo. org

Quézel P, Médail F (2003) Écologie et biogéographie des forêts du basin méditerranéen. Elsevier, Paris

Rivas-Martínez S, Peñas A, Díaz TE (2004) Bioclimatic map of Europe thermoclimatic belts. Cartographic Service, University of León, León, http://www.globalbioclimatics.org/form/tb med.htm. Accessed October 2017 
Roberts N, Eastwood WJ, Kuzucuoğlu C, Fiorentino G, Caracuta V (2011) Climatic, vegetation and cultural change in the Eastern Mediterranean during the mid-Holocene environmental transitions. Holocene 21:147-162. https://doi.org/10.1177/0959683610386819

Robinson SA, Black S, Sellwood BW, Valdes PJ (2006) A review of palaeoclimates and palaeoenvironments in the Levant and Eastern Mediterranean from 25,000 to 5000 years BP: setting the environmental background for the evolution of human civilisation. Quat Sci Rev 25:1517-1541. https://doi.org/10.1016/j.quascirev.2006.02.006

Rodríguez-Garcia E, Mezquida ET, Olano JM (2017) You'd better walk alone: changes in forest composition affect pollination efficiency and pre-dispersal cone damage in Iberian Juniperus thurifera forests. Plant Biol (Suttgart) 19:934-941. https://doi.org/10.1111/plb.12613

Rodríguez-Sanchéz F, Arroyo J (2008) Reconstructing the demise of Tethyan plants: climate-driven range dynamics of Laurus since the Pliocene. Glob Ecol Biogeogr 17:685-695. https://doi.org/10.1111/ j.1466-8238.2008.00410.x

Romo A, Iszkuło G, Taleb MS, Walas Ł, Boratyński A (2017) Taxus baccata in Morocco: a tree in regression in its southern extreme. Dendrobiology 78:63-74. https://doi.org/10.12657/denbio.078.007

Sarıkaya MA, Çiner A, Zreda M (2011) Quaternary glaciations of Turkey. In: Ehlers JP, Gibbard PL, Hughes PD (eds), Quaternary glaciations. Extent and chronology. Develop Quater Sci 15:393-403

Schiechtl HM, Stern R, Weiss EH (1965) In Anatolischen Gebirgen: Botanische, forstliche und geologische Studien im Kilikischen Ala Dag und Ostpontischen Gebirge von Kleinasien. Verl Geschichtsver Kärnten (Klagenfurt) 31:1-187

Schmucker T (1942) Die Baumarten der nördlich-gemässigten Zone und ihre Verbreitung Silvae Orbis 4. CIC, Berlin-Wannsee

Sobierajska K, Boratyńska K, Jasińska A, Dering M, Ok T, Douaihy B, Dagher-Kharrat MB, Romo A, Boratyński A (2016) Effect of the Aegean Sea barrier between Europe and Asia on differentiation in Juniperus drupacea (Cupressaceae). Bot J Linn Soc 180:365-385. https://doi.org/10.1111/boj.12377

Stockey RA, Kvaček J, Hill RS, Rothwell GW, Kvaček Z (2005) The fossil record of Cupressaceae sensu lato. In: Farjon A (ed) A monograph of Cupressaceae and Sciadopitys. Royal Botanic Gardens, Kew, pp 54-68

Talhouk SN, Zurayk R, Khuri S (2001) Conservation of the coniferous forests of Lebanon: past, present and future prospects. Oryx 35:206215. https://doi.org/10.1046/j.1365-3008.2001.00180.x

Tan K, Sfikas G, Vold G (1999) Juniperus drupacea (Cupressaceae) in the southern Peloponnese. Acta Bot Fenn 162:133-135

Tang CQ, Dong Y-F, Herrando-Moraira S, Matsui T, Ohashi H, He L-Y, Nakao K, Tanaka N, Tomita M, Li X-S, Yan H-Z, Peng M-C, Hu J, Yang R-H, Li W-J, Yan K, Hou X, Zhang Z-Y, López-Pujol J (2017) Potential effects of climate change on geographic distribution of the Tertiary relict tree species Davidia involucrata in China. Sci Rep 7: 43822. https://doi.org/10.1038/srep43822

Thompson JD (2005) Plant evolution in the Mediterranean. Oxford University Press, Oxford. https://doi.org/10.1093/acprof:oso/ 9780198515340.001 .0001

Title PO, Bemmels JB (2018) ENVIREM: an expanded set of bioclimatic and topographic variables increases flexibility and improves performance of ecological niche modeling. Ecography 41:291307. https://doi.org/10.1111/ecog.02880

Touchan R, Anchukaitis KJ, Shishov VV, Sivrikaya F, Attieh J, Ketmen M, Stephan J, Mitsopoulos I, Christou A, Meko DM (2014) Spatial patterns of Eastern Mediterranean climate influence on tree growth. The Holocene 24:381-392. https://doi.org/10.1177/ 0959683613518594

Türkeş M (2003) Spatial and temporal variations in precipitation and aridity index series of Turkey. In: Bolle HJ (ed) Mediterranean climate. Springer, Berlin, Heidelberg, pp 181-213

Tylkowski T (2009) Improving seed germination and seedling emergence in the Juniperus communis. Dendrobiology 61:47-53

Tylkowski T (2010) Dormancy breaking in savin juniper (Juniperus sabina L.) seeds. Acta Soc Bot Pol 79:27-29. https://doi.org/10. 5586/asbp.2010.004

Tzedakis PC (2004) The Balkans as prime glacial refugial territory of European temperate trees. In: Griffiths HI, Kryštufek B, Reed JM (eds) Balkan biodiversity. Kluwer, London, pp 49-68. https://doi. org/10.1007/978-1-4020-2854-0

Ünal Y, Kindap T, Karaca M (2003) Redefining the climate zones of Turkey using cluster analysis. Intern J Clim 23:1045-1055. https:// doi.org/10.1002/joc. 910

Velitzelos D, Bouchal JM, Denk T (2014) Review of the Cenozoic floras and vegetation of Greece. Rev Paleobot Palyn 204:56-117. https:// doi.org/10.1016/j.revpalbo.2014.02.006

Vermoere M, Degryseb P, Vanhecke L, Muchez P, Paulissend E, Smets E, Waelkens M (1999) Pollen analysis of two travertine sections in Basköy (southwestern Turkey): implications for environmental conditions during the early Holocene. Rev Palaeobot Palyn 105:93110. https://doi.org/10.1016/S0034-6667(98)00068-2

Wang Z, Chang YCI, Ying Z, Zhu L, Yang Y (2007) A parsimonious threshold-independent protein feature selection method through the area under receiver operating characteristic curve. Bioinformatics 23:2788-2794. https://doi.org/10.1093/bioinformatics/btm442

Wazen N, Fady B (2015) Geographic distribution of 24 major tree species in the Mediterranean and their genetic resources. FFEM project: maximize the production of goods and services by Mediterranean forests in a context of global changes. INRA-URFM, Avignon

Willis JK, McElwain JC (2002) The evolution of plants, vol 90. Oxford University Press, Oxford, pp 678-679. https://doi.org/10.1093/aob/ $\operatorname{mcf} 232$

Yaltırık F (1993) Dendroloji I Ders Kitabı Gymnospermae (Açık Tohumlular). İstanbul Üniversitesi, Orman Fakültesi Yayınları 3443/386, İstanbul

Zohary M (1973) Geobotanical foundations of the Middle East. Fischer Swets and Zeitlinger, Stuttgart-Amsterdam

Publisher's note Springer Nature remains neutral with regard to jurisdictional claims in published maps and institutional affiliations. 